\title{
Australian Fire Ceremonies: Lartna and Engwura in the Arrernte Tribe
}

\author{
Andrzej Szyjewski iDhttps://orcid.org/0000-0002-1190-4035 \\ Institute for the Study of Religions \\ Jagiellonian University \\ andrzej.szyjewski@uj.edu.pl
}

\begin{abstract}
Comparing the cycle of initiation rites in the Arrernte with initiation rituals in the desert tribes, we arrive at the conclusion that they are based upon an analogous symbolism of activities and ideas. The Arrernte initiations are therefore a transformation of the desert rites in which the ritual syntagmas are distributed differently. An example supporting this thesis is the use of tall torches of the witi/widi type in the circumcision rite instead of in the "proper" fire ceremony, the fact that they are not lit despite the presence of the symbolism of fire in the ritual songs, and the role of women in their destruction. The founding myth of the Engwura is at the same time a myth that introduces circumcision (Lartna), and both of these ritual activities are treated interchangeably in variants of the myth. The Engwura itself, as a fire ceremony, has to be considered the final and crowning phase of the initiation processes. It is characterised by the presence, shared with the Western Desert, of a symbolic complex in which a special role is played by the equivalence: adepts $\equiv$ Eremophila $\equiv$ torch fire. Due to the fact that use of Eremophila, on the one hand, refers to the symbolism of the monsoon season (the greenness of the plant) and, on the other hand, to fires of the dry season (the redness of the plant and associations with the emu), it constitutes an ideal operator for the initiation process.
\end{abstract}

Keywords: Australian Aborigines, Arrernte, rituals, myth, initiation symbolism, subincision, Eremophila longifolia, gender symbolism

Słowa kluczowe: australijscy Aborygeni, Arrernte, rytuał, mit, symbolika inicjacyjna, subincyzja, Eremophila longifolia, symbolika płci 


\section{Introduction}

The present article attempts to recapitulate the meanings of the symbolism of fire used in initiation rituals in the Arrernte tribe. ${ }^{1}$ By comparing the obtained results with analyses of the ritual use of fire by the desert Warlpiri people, conducted in earlier texts, it is possible to determine which elements of the symbolic field of fire are common to Australian Aborigines, as well as to indicate rules of their transformation. A comparison of this aspect of the initiation ceremonies should enable us to establish to what extent the fire ceremonies constitute a common foundation for Australian Aboriginal religious life, and to what extent they are a relatively new ritual system, spreading in a similar manner to that of the Kurangara, as has been seen in analyses by N. Peterson or M. Meggitt. ${ }^{2}$

No analysis of Australian fire ceremonies can be carried out without referring to the Engwura/Inküra in the Arrernte tribe. Since Spencer and Gillen's account is the only comprehensive description of this ceremony, ${ }^{3}$ we will concentrate on it, supplementing it with data provided by T.G.H. Strehlow and other authors. According to Spencer and Gillen, the Engwura is a complex of ceremonies that ends the initiation process after the adepts have undergone subincision. Essentially, there are two forms of the Engwura. The first one, defined as the Urumpilla ${ }^{4}$ is a shortened version of the ceremony, performed in various clans for several days. The second form - the "real" Engwura - is a four-month ceremony, dedicated to the ancestors of the Achilpa clan, especially to the peregrination of their leader Inkata Achilpa maraknirra, when the Ambilia-ekura paraphernalia are used as an attribute of this ancestor and a medium of the power of Dreaming passed over to the ancestors of the Achilpa. In this form, it is a complex of several dozen ceremonies in which various totems participate, ending with a fire trial. T.G.H. Strehlow, on the other hand, defines the Engwura in the following manner:

An inkŭra festival is a ceremonial festival held at a pmara kutata, during which the complete local ceremonial cycle is enacted. The site where these acts take place is known as a ceremonial inkŭra ground (Arrernte rala inkŭra). ${ }^{5}$

${ }^{1}$ The article constitutes a continuation of texts published in "Studia Religiologica" 2014, vol. 47, no. 1, vol. 47, no. 2 and 2016, vol. 49, no. 3, dedicated to the analysis of Australian fire ceremonies.

2 A discussion of this problem was presented in the article: A. Szyjewski, Australijskie ceremonie ognia. Ogień w religii Warlpiri, "Studia Religiologica" 2014, vol. 47, no. 1, pp. 33-35.

${ }^{3}$ R.G. Kimber, M.A. Smith, An Arrernte Ceremony, [in:] Australians to 1788, D.J. Mulvaney, J.P. White (eds.), Fairfax 1987, pp. 221-237.

${ }^{4}$ In both cases the name includes the root ûra- "fire." An alternative explanation links the term engwura to the Pitjantjatjara term ngulu, which denotes a devout awe, fear and, at the same time, serves as a name of the so-called "Ceremony of the Red Ochre," the name of a series of male initiations in the Pitjantjatjara. See: W. Hilliard, The People in between: The Pitjantjatjara People of Ernabella, New York 1968, p. 123.

${ }^{5}$ T.G.H. Strehlow, The Songs of Central Australia, Melbourne 1971, p. 748. Strehlow also talks about the inkŭra in terms of a "cycle of ceremonies." 
This means that in his opinion there is no indissoluble relationship between the Engwura and the Achilpa clan, and that every performance of a full ceremonial cycle belonging to a particular great totemic centre (pmara kutata) is called inkŭra.

Spencer and Gillen participated together in a great Engwura that took place near Alice Springs, from October to December 1896 (the introductory ceremonies started in mid-September, whereas the final ones were still being performed in mid-January $1897^{6}$ ). The site where the ceremonies were conducted requires a longer commentary. According to Gillen, the Engwura "is performed at various places and at long intervals throughout the whole tribe. Churinga from all parts of the ceremony are brought together. The performance extends over many days and the various attend from hundreds of miles around." "According to T.G.H. Strehlow, the ceremonies are always bound to a specific place that constitutes the main totemic centre (pmara kutata "everlasting home") for all the Arrernte groups possessing this totem (which has been confirmed by Spencer and Gillen themselves with reference to the standard totemic ceremonies of the Quabara ${ }^{8}$ ). The described Engwura belonged to the totemic centre of Imanda associated with the totem of the Frog (Unchichera in Spencer and Gillen's book; Intjtjera in Strehlow's) and the White Bat ${ }^{9}$ (Erlkintera in Spencer and Gillen's account, Ulbolbuna in that of Strehlow) on the territory of the southern Arrernte. Strehlow's informer, a member of the northern Arrernte, claimed that Ilbalintja, which is the biggest totemic centre for the Bandicoot group, is such a pmara kutata in which the northern Arrernte would always perform the ceremonies of the Engwura (ingkura). For the southern Arrernte, however, such a site is Imanda, in which the inküra is dedicated in the first place to the totem of the Frog and Bat.

Yielding to Gillen's requests, the owner of the ceremonies had decided that they would take place in a different totemic centre, i.e., Choritcha/Tjoritja (Alice Springs), belonging to the Witchetty Grub clan (Udnirringita in Spencer and Gillen's account, Tnurungatja in Strehlow's). Thanks to this, the researchers had easy access to the ceremonial ground and could bring in supplies from Alice Springs, with which they would normally pay the Aborigines for performing the ceremony. However, because of the change of location, the traditions of the southern Arrernte from Imanda were transferred to the territory of the eastern Arrernte from Alice Springs, which, in the opinion of Strehlow's informers, constituted a serious violation of the Engwura rules, verging on sacrilege. ${ }^{10}$ Spencer and Gillen have explained this by the fact that Erlkintera, the Inkata of the Achilpa clan from Imanda, felt too old to perform the rituals and ceded his rights to his brother, Arrai-iga, from the Emu ${ }^{11}$ clan. In addition,

${ }^{6}$ B. Spencer, F.J. Gillen, Native Tribes of Central Australia, London 1899, p. 272; eidem, The Arunta, vol. 1, London 1927, p. 225; eidem, Across Australia, London 1912, vol. 2, p. 258.

${ }^{7}$ F.J. Gillen, Letter 23, [in:] My Dear Spencer: The Letters of F.J. Gillen to Baldwin Spencer, J. Mulvaney, H. Morphy, A. Petch (eds.), Melbourne 1997, pp. 131-132.

${ }^{8}$ B. Spencer, F.J. Gillen, Native Tribes..., op. cit., pp. 119-120; eidem, The Arunta, op. cit., p. 72.

9 The greater false vampire bat (Macroderma gigas) is the biggest carnivorous bat in Australia.

${ }_{10}$ T.G.H. Strehlow, The Songs of Central Australia..., op. cit., p. XXIII; idem, Aranda Traditions, Melbourne 1947, pp. 109-110.

${ }^{11}$ B. Spencer, J.F. Gillen, The Arunta..., op. cit., fig. 2, p. 12. Elsewhere, Spencer claims that he was his son, not brother (p. 233). 
Unchalka, the Inkata Udnirringita (i.e., alatunja), was a great friend of Gillen ${ }^{12}$ and, in the end, this probably settled the issue of site selection.

We are facing a difference in treatment of the Engwura by T.G.H. Strehlow and by Spencer and Gillen. Strehlow claims that:

[...] most of the sacred ceremonies witnessed by Spencer and Gillen in 1896-1897 on the igkŭra ground at Alice Springs were actually commemorative ceremonies in honour of various totemic ancestors, and not initiation ceremonies in the generally accepted significance of this term. They could have been enacted on their own quite apart from any initiation festival, and they would still have fulfilled their intended function: to bring the totemic ancestors before their human worshippers in a form in which they could be honoured in song and dance. ${ }^{13}$

Yet he further states explicitly that participation in the Engwura ended a five-stage process of becoming a male, through a series of initiations, ${ }^{14}$ and that the ancestors of the Achilpa clan (Tjilpa in his terminology) had introduced initiation ceremonies connected with subincision. ${ }^{15}$ In other words, according to him, many of the rituals described in detail by Spencer and Gillen are not structurally linked to the initiation system of the Engwura. The author does not, however, provide an answer to the question concerning what really belongs to the Engwura in the initiatory sense and, in particular, what aspects of such ritual activities are supported by Achilpa mythology. For both of the Engwura scenarios described in detail by Strehlow: the inkura of the Bandicoot clan from Ilbalintja (May 1933) ${ }^{16}$ and that of the Western Quoll clan from Ltalaltuma, ${ }^{17}$ include the motif of ancestors of the Tjilpa (Achilpa) who used the Kanaua pole. The founding myth of the Engwura talks quite unequivocally about the beginning of the ritual in the context of an initiation cycle, strongly linking the act of circumcision to the use of fire by the first Achilpa, under the command of the Inkata kupitcha. I think that his words can be interpreted in the following way. The Engwura (igkurra) is the last stage of initiation, requiring a recreation of the entire complex of rituals associated with the given great totemic centre. The so-called "small Engwura" is essentially a "private" recreation of a part of this complex, which can be performed each year. However, such elements as the parra mound, the Ambilia-ekura and the Kauaua pole are the property of the entire clan - they are not private; therefore, they can be used exclusively in the context of the "great" Engwura. It is not clear whether this refers only to the Achilpa (Tjilpa) clan, because Strehlow also talks about them in the context of the Bandicoot clan centre in Ilbalintja.

${ }^{12}$ F.J. Gillen, Letter 15..., op. cit., p. 83.

13 T.G.H. Strehlow, The Songs of Central Australia..., op. cit., p. 349.

${ }^{14}$ Ibidem, p. 395. Spencer and Gillen write about it in the exact same manner (Native Tribes..., op. cit., p. 213; The Arunta..., op. cit., p. 175).

15 T.G.H. Strehlow, The Songs of Central Australia..., op. cit., p. 403.

16 Ibidem, pp. 358-379.

${ }^{17}$ Ibidem, pp. 403-409. 


\section{The Arachitta poles and fire}

Before we move on to an analysis of the Engwura ceremony, it needs to be stressed that the use of the symbolism of fire in the Arrernte rituals differs from the tradition of the Western Desert tribes. This distinction pertains, in the first place, to the presence of a complex of wanmanmiri/widi poles/torches. The Engwura is in reality a several-month ceremonial complex, within which a variety of ritual activities can be observed. In none of them, however, are there torches corresponding to those of the widi or wanmanmiri type. But they can be observed in an earlier phase of the initiation process, namely during the circumcision ceremony (Spencer and Gillen: Lartna; Strehlow: Látnua, Intunama).

When comparing the Lartna scenario in the Arrernte with the Kurdiji in the Warlpiri, one can easily notice analogous patterns of the ritual use of fire. The ceremony of throwing the initiate up in the air (Alkirakiwuma) is an introduction to the initiation process. Its counterpart in the Warlpiri tribe is the Marnakurrawarnu ("leaving the shelter"). Subsequently, the initiate becomes an object of a struggle between the male and the female sphere. The female side is represented by impersonators of women called Unt(h)ippa (Ndápa in Strehlow's terminology), who dance with shields (alkuta) with which they hit the ground (the sound of which drives the men-Hawks mad in the myth). ${ }^{18}$ In the Kurdiji, the women who kidnap the adept are repelled with the use of fire. The same episode is also familiar to the Warramunga in their initial ceremony of the Walunkun. In the Arrernte, in the Unchalkunkna ceremony, there also appears a complex of torches that symbolizes the adept's life:

The oldest Mia woman of the boy ${ }^{19}$ (his actual Mia or mother being dead) had brought with her from her own camp a fire-stick, which she had been careful to keep alight all night. At daylight she lit a fire by means of this, and then took two long sticks with which she had provided herself, and, lighting them at the fire, went and sat down, holding them in her hands, immediately behind the Urinthantima ${ }^{20}$ man. The Uwinna, that is the sisters of the boy's father, went and also sat down along with her. Then, as the men began to sing a special fire song, she handed one of the fire-sticks to the woman who was the Mura tualcha of the boy, that is the woman whose eldest daughter, born or unborn, has been assigned to the Wurtja as his future wife, so that she is potentially his mother-in-law. While the singing went on this woman approached the boy, and, after tying round his neck bands of fur string, she handed to him the fire-stick, ${ }^{21}$ telling him as she did so to always hold fast to his own fire - in other words not to interfere with women assigned to other men. ${ }^{22}$

${ }^{18}$ Ibidem, p. 395. It constitutes a significant reversal of the activities carried out in the course of the Bora/Burbung in the south-east. There, the men hit the ground with pieces of munga bark, telling the women or the adepts lying under blankets on the ground that it is the sound of Daramulun's steps, of whom they should be afraid. R.H. Mathews, The Burbung of the Wiradthuri Tribes, "Journal of the Royal Anthropological Institute" 1896, vol. 25, p. 308.

19 The initiated boy's mother or aunt.

${ }^{20}$ The task of the Untinthaminy is to support the shield onto which the initiate's blood drops during the circumcision operation. When the torch is handed over, the adept sits on his knees.

${ }^{21}$ The handing over of the torch is called the Unchalkulkna. It is believed that its fire is of sacred character [note - B. Spencer, F.J. Gillen].

22 B. Spencer, F.J. Gillen, Native Tribes..., op. cit., p. 222; eidem, The Arunta ..., op. cit., pp. 182-183. 
Both the adept (Wurtja) and Mia look after their fire-sticks throughout the night, preventing them from going out, because otherwise they would die from the kurdaitcha spells. The fire-sticks can be disposed of only when the initiate is taken back to the camp.

The double waninga Jarandalba (or Warumbulga) characteristic of the Warlpiri, which was earlier deemed to be the counterpart of the Southern Cross against the background of the Milky Way, ${ }^{23}$ appears in the Arrernte rituals as the waninga that represents an old man kangaroo and his son. ${ }^{24}$ A pair of men who hold the waninga walk the Apulla (Strehlow: pula) path, stop in front of the Wurtja and swing it over the boy's head. Subsequently, the waninga is fixed upright in the path in front of the initiate, who is now able to look at it for the first time and embrace it, in order to gain the strength necessary for the operation. While this happens, the hierophants explain the meaning of the waninga to the boy. Next, they decorate the initiate's head with stalks of cane grass. ${ }^{25}$ Then they decorate themselves in the same manner, additionally inserting stalks beneath their arm bands. It can be assumed that it constitutes a ritual of acknowledging "male unity" with the Wurtja; it is probably also a reference to the process of vegetation.

Despite these important similarities, in the circumcision rite in the Arrernte, fire does not function as an active operator. ${ }^{26}$ This does not mean that it is absent from the textual layer of the ceremony. The same classificatory mother-in-law (Mura) who handed the fire-stick to the initiate (Wurtja) during the initial rite, reappears after the initiate has been presented with the waninga as an impersonator of the Untippa women. While the other women dance in front of the men, gathered behind their pile of wood, and husk stalks of cane grass from their heads, the Mura kidnaps the boy, hoisting him on to her shoulders, runs off with him outside the Apulla, and sits him on the ground in a place located nearby. The women perform a characteristic seductive dance in front of him, moving their hands as if beckoning the Wurtja to them. At this time, the men chant the fire song, which evidently incorporates the circumcision rite into the sphere of the symbolism of fire. According to Spencer and Gillen's transcription, it takes the following form:

Atnylinga etunja illa altara wuntama

"red flower of Eremophila... a twig of Eucalyptus... blazing up... rushing along"27

Eremophila is an Australian species of shrubs and herbs belonging to the family of Scrophulariaceae, growing even in desert areas that were most unfavorable for vegetation. It blooms in the winter season (May-November). Flowers of Eremophila have

${ }^{23}$ A. Szyjewski, Australijskie ceremonie ognia. Gadjari i Buluwandi u Warlpiri, "Studia Religiologica" 2014, vol. 47, no. 3, p. 209.

${ }_{24}$ B. Spencer, F.J. Gillen, Native Tribes..., op. cit., p. 238; eidem, The Arunta..., op. cit., p. 194; C. Strehlow, Die Arrernte und Loritja Stämme in Zentral-Australien, Bd. 4, Frankfurt 1913, pp. 22-23.

${ }^{25}$ Probably swamp cane grass [Eragrostis australasica] that grows on periodically flooded land.

${ }^{26}$ Carl Strehlow mentions throwing fire projectiles over the adepts' heads. C. Strehlow, op. cit., p. 20.

${ }_{27}$ B. Spencer, F.J. Gillen, Native Tribes..., op. cit., p. 238; eidem, The Arunta..., op. cit., p. 195. 
a characteristic shape, with a declining lower part of the calyx that creates a landing place for insects, which may be associated with a penis. Among numerous species of Eremophila, E. maculeata (Arrernte: atnylinga) plays the most important symbolic role. It is also called spotted emu bush, because emus willingly eat its fruits, and its seeds can be found in excrements of these animals. Aborigines value the red flowers of E. alternifolia more than its fruits, which are considered to be poisonous and firm. The flowers are filled with sweet nectar that can be sucked after the plant is cut. The remaining species of Eremophila are usually used as herbs, from which infusions that cure wounds, pain, cold and infertility can be prepared. ${ }^{28}$

From the point of view of the Arrernte, an important fact is that Eremophila longifolia is the basic plant on which feeds the caterpillar of the Coenotes eremophilae moth, also called the Emu Bush Caterpillar or Hawk Moth, from the Sphingidae family. ${ }^{29}$ Their butterflies can hover in one place drinking nectar, like hummingbirds, whereas their caterpillars have a special horn at the end of their corpus, which can probably be related to phallic symbolism in the same way as the flowers of Eremophila.

According to Spencer and Gillen's informants, the colour of the flowers is associated with a great mythic fire from which they got their deep red tint. It is probably the same fire that the Warramunga ascribe to the brother-Hawks, ${ }^{30}$ and the desert tribes - to Moloch. The Eremophila mentioned in the fire song combines, therefore, fire and protection against it, Emu and ritual surgery (resin from Eremophila functions as a plaster, whereas an infusion made from this plant draws pus away from the wound). In the Warlpiri, during the Gadjari, Eremophila symbolizes both the adepts themselves and the fire-sticks, and protects against fire, analogically to the ceremony of the Engwura in the Arrernte, to which we will return later. Among researchers who investigate Aborigines, only R.H. Mathews seems to be solving the puzzle as to why Eremophila symbolizes the adepts. In the south-east, in the ceremonies of the Keeparra, the women - after the initiates have been kidnapped by the men - pick a twig of Eremophila and place it in a stick-digger. When the twig withers and its leaves go dry, the return of the "digested" initiates can be expected. ${ }^{31}$ This points to an essential unity between the initiated boys and the green plants, analogous to a unity between the initiates and the torch fire.

${ }^{28}$ G.S. Richmond, A Review of the Use of Eremophila (Myoporaceae) by Australian Aborigines, "Adelaide Botanic Garden" 1993, no. 15 (2), pp. 101-107.

29 The Arrernte call it tnwerrengatye (in contemporary spelling), Strehlow writes tnurungatja, whereas Spencer and Gillen - Udnirringita. Yet it was Spencer and Gillen who had confused this edible caterpillar with a different one, called Witchetty (wijuti) [Encoxyla leucomochia], which feeds on Acacia kempeana, commonly known as witchetty bush, under the roots of which it digs tunnels. For this reason, Spencer and Gillen use a number of the Arrernte spellings of the name Eremophila, calling it Atnylinga, Atnyringa and Udnirringa.

${ }^{30}$ A. Szyjewski, Australijskie ceremonie ognia. Ceremonie Wollunki u Warramunga, "Studia Religiologica" 2016, vol. 49, no. 3, pp. 233-234. It seems that a certain form of this myth also functions in the Arrernte. Theodor Strehlow mentions a comic episode depicting the ancestor - Hawk Inkaninkana burning his sons and also himself. T.G.H. Strehlow, The Songs of Central Australia..., op. cit., p. 379.

${ }^{31}$ R.H. Mathews, The Keeparra Ceremony of Initiation, "Journal of Anthropological Institute" 1897, vol. 26, p. 329. 
Another plant of great ritual importance is the red river gum (Eucalyptus camaldulensis), whose twigs (etunja), saturated with essential oils, will be used to wrap poles functioning as the counterparts of the widi/wanbanbirri torches. During their preparation, the fire song is sung again. Before this happens, the Wurtja is retaken by the classificatory fathers-in-law under the command of the Urinthantima, and listens to the fire song that is sung all night long (although he cannot see anything). At dawn, the women return to the Apulla and try to "seduce" the adept; yet this time the Urinthantima hoists the boy on to his shoulders and kidnaps him to a place where the men prepare several-meter long poles, wrapped in leafy eucalyptus twigs, called the Arachitta $^{32}$ Picking up the twigs, they sing a song about their preparation and then the fire song.

In this context, it seems very odd that the Arachitta poles are not used as torches; they are not ignited, despite the fact that during their preparation a song about fire and burning is sung. Fire appears only during their preparation - the fire song is sung, when the eucalyptus twigs are first slightly scorched and then wrapped around the poles. The women are again repelled, this time with the use of projectiles in the form of pieces of ilyabura bark (also not ignited) thrown at them, against which they protect themselves with shields.

The introduction of the Arachitta into the ceremonial ground takes place in a special manner, which is very similar to the way in which the widi are used among the Warlpiri.

[...] the men who had previously made the Arachitta poles ran away from the Apulla, shouting, "Pai! pai! pai!" and brought the poles back with them from where they had been deposited. When within about fifty yards of the Wurtja they separated into two parties, one crossed in front of him from left to right, and the other from right to left, and the poles were deposited about twenty yards to either side of him; what was the meaning of this cannot be said, the native explanation as usual being that it was thus done in the Alcheringa. ${ }^{33}$

Next, the men attach the poles to their ankles (unlike in the desert tradition with the help of women) and dance. Suddenly, they throw themselves at the adept, covering him with their bodies, and hit the twigs as if whipping the boy. Doing so, they sing: Ingwa alkirna alkirna li/Urtnatha alkirla impara ("twilight... a great clear light... night... trees growing close together...like the sky... rising red [like the sun]..."). The women, following the dancers, pull out the braided etunja twigs from the dancers, whereas in the northern Arrernte they pull them out from the Arachitta, ${ }^{34}$ which are fixed into the ground. One way or another, it is not the Arachitta poles that are set on fire, but the twigs from which two piles on the sides of the Apulla ground

32 In Report on the Work of the Horn Expedition to Central Australia, B. Spencer (ed.), London 1896, vol. IV - Anthropology, p. 170, the term Arachitta denotes a double row of spears from which, after fixing them into the ground, "torches" are constructed. In The Arunta (p. 348), in the totemic myth of Fire, there appears the term urunchitta (in: Native Tribes [p. 445]; this word is spelled urunchitha, which means that it has been corrected by Spencer), which is translated as "a spark of fire."

33 B. Spencer, F.J. Gillen, Native Tribes..., op. cit., pp. 242-243; eidem, The Arunta..., op. cit., pp. 199-200.

34 B. Spencer, F.J. Gillen, Native Tribes..., op. cit., p. 244; eidem, The Arunta, op. cit., p. 201. 
had been built earlier, now thrown onto one great pile. The pile of twigs is set on fire in order to illuminate the Lartna operation. After the operation, the Wurtja crouches over a shield, awaiting the bleeding to diminish. Then the Arachitta poles appear for the last time:

After a time, when the bleeding had diminished, he was led to the eastern end of the Apulla, where he stood between two Kullia looking towards the west, while two other Kullia [older classificatory brothers who were his guards - A.S.], each taking an Arachitta pole, mounted the bank and holding their poles over the path shouted loudly, moving them up and down as they did so, "Arara, arara, arara," which is the signal for the officials, who had been standing on one side in the shade, to come on to the Apulla ground once more. ${ }^{35}$

Fire is an important element in the structure of the rite. It appears in opposition to the female power, embodied by the mythical Untippa ${ }^{36}$ women - role-played by, successively, the classificatory mothers (Mia) and mothers-in-law (Mura) of the boy - who kidnap the mythical initiate. This means that the mythical torch fire, with which women would perform circumcision, becomes transformed into the ritual fire of hearth and home. The dread of destructive circumcisions performed with the use of fire is present in the rite in the form of a warning addressed to the adept, implying that he should mind his own hearth and home, i.e., not be interested in extramarital sex. Nevertheless, the women are several times repelled by the initiate, which is preceded by the singing of the fire song by the men. The Arachitta poles that have been prepared by the men are to protect the adept against the negative effects of the operation itself, but also against the women's attacks. An important ritual procedure associated with the Arachitta poles is dividing them into two rows and situating them at the two sides of the Apulla path. The carriers of the widi in the ceremony of the Buluwandi in the Warlpiri, described by Peterson, act in the exact same manner. Yet the Buluwandi is a ceremony that crowns the initiation cycle and the symbolism of such a division refers more to subincision. ${ }^{37}$ However, if we assume that the Arachitta refer to the symbolism of the Milky Way, as the widi in the desert tribes, then the ritual message becomes understandable within the code of the vegetation cycle. The adepts become circumcised as an analogy to the bush being burnt by fires, which is predicted by the change of localization of the Milky Way in the sky from vertical to horizontal. As a consequence, the initiates are an embodiment of a "new" vegetation, of which the quintessence is Eremophila longifolia. This equivalence is reflected in the decoration of the adepts with the twigs of Eremophila. The women pluck the twigs both from the male decorations and from the Arachitta, which, in the context of the Warlpiri's rites analysed earlier, would signify an attempt at taking over the fertilizing power of these decorations.

Finally, fire contributes to healing the initiation wounds. This is why the adept stands for a while over the fire, the smoke of which has properties that stop the

${ }_{35}$ B. Spencer, F.J. Gillen, Native Tribes..., op. cit., p. 248; eidem, The Arunta, op. cit., p. 203.

${ }^{36}$ The issue of the Untippa women will be discussed in detail in the section analyzing the founding myth of the Engwura.

${ }^{37}$ A. Szyjewski, Australijskie ceremonie ognia. Gadjari i Buluwandi u Warlpiri, op. cit., p. 207-210. 
bleeding and accelerate healing ${ }^{38}$ (n.b., like the juice from Eremophila). Fumigation (together with injuring of the head) is considered by Strehlow to be the next, fourth phase of initiation, which is lacking in Spencer and Gillen's account. ${ }^{39}$ "The fire ceremony is certainly an ordeal, but is also frequently regarded as an act of purification, making it safe for the newly initiated to return to the world of everyday life. This explains why it is usually the final rite in the series." ${ }^{40}$

\section{The Engwura scenario}

Spencer and Gillen, who participated in the "full" Engwura, claimed that it consisted of four phases which depended on the degree of secrecy and intensity of the ritual activities.

1. The public phase. As many of the tribe members as possible gather, summoned by messengers. After performing some introductory rites of the Atnimoketa and the Illyanpa, secular corroborees in which women can participate, a secret ground called the Apulla is prepared, of which the most important part is the parra mound ("penis").

2. The initiated men, after separating themselves from the women, move to the Engwura ground, which commences secret activities. For six weeks, secret rites of the Quabara, devoted to the totems engaged in the wanderings of the Achilpa, are performed. The sequence of rites is not strictly fixed. In the north, the tnatantja/nurtunja are used, in the south - the waninga. This phase ends with decoration of the adepts with Eremophila (= wetta) twigs, which makes the initiates look similar to the Arachitta poles. From now on they are called the Ilpongworra ("ungreased men").

3. Other groups arrive, and the ceremonial activity concentrates on checking the churinga that have been brought. Further secret totemic ceremonies are performed, including those devoted to the demonic spirits eruncha/oruncha, the Ambaquerka (the ceremony of the Plum Tree) dedicated to the Perta ratappa stone, and the ceremony of the Opossum (Anthinna), and the Frog, linked to the myth of Achilpa's peregrination. In the end, the green eucalyptus twigs are removed from the Parra, and the adepts, who have been lying with their heads on it until now, move to the river. The elders, after decorating the impersonator of the Frog with a representation of eucalyptus from Imanda, start to spin their bull-roarers, which scares away the initiates from the river bank and directs them to the Engwura ground.

4. The final stage, associated with the use of fire, has been discussed in detail below.

${ }^{38}$ B. Spencer, J.F. Gillen, The Arunta..., op. cit., p. 205.

39 A.P. Elkin deems the presence of fire in initiation complexes to be an Aboriginal universality that manifests itself in various ways. A.P. Elkin, The Australian Aborigines, New York 1964, p. 183.

40 Ibidem, p. 184. 
In the course of the Engwura, fire appears when the freshly initiated men (Illpongworra) cross the creek that separates them from the female side of the camp. The initiates are decorated with green twigs of Eremophila as if they themselves were the Arachitta poles. The women await them by two large fires lit by the two moieties, and with dance and gestures encourage them to come closer. When this happens, they try to set the Illpongworra's decorations on fire with the use of burning wisps of grass. The Illpongworra defend themselves with the use of Udnirringa twigs, which they are holding in their hands. Eventually, they flee to their side of the creek, where they lie down on the east side of the Parra mound. Then a dance is performed, in which four impersonators of the evil spirits (eruncha) enact a scene of roasting youths in a cooking pit (this complex, which combines the symbolism of the Engwura and the Bora initiation from the south-west, will be analysed later). These activities are repeated several times, always at night. They end with a retaliatory action conducted by the men, who ignite bundles of twigs, cross the creek and surround the women from three sides. Then the men throw the burning twigs over the women's heads, who protect themselves against the falling embers with the use of green twigs. However, before this happens, it is necessary to erect the Kauaua (Kauwa-auwa) pole and prepare the sacred object called Ambilia-ekura which, after the attack, is carried to the women's side, where it is protected from their sight by covering it with the bodies of the Illpongworra adepts and other initiated men. This means that the Ambilia-ekura reverses the relation between what is male and what is female. "The natives say, further, that the first rushing across to the women's camp represents an attack by a party of Achilpa men, who are Ilpongworra and not yet made into Urliara, upon other party, and that the lying down quietly in the front of the Ambilia-churra represents the "taming' of the wild men under the influence of the Churinga." ${ }^{41}$

After erecting the Kauaua, the Illpongworra adepts are escorted to a selected place nearby, where a bonfire is lit and then covered with green twigs. The adepts lie down on them, immersed in the smoke. The green twigs protect them from direct contact with fire; nevertheless, they lie in the hot bonfire twice, each time for approximately five minutes. In the evening, fire-sticks are ignited around the Kauaua and in the women's camp.

All night long also the old men kept shouting across to the women, who answered back again, and the scene was one of great excitement. An old man would shout out, "What are you doing?" and the women would answer, "We are making a fire." "What are you going to do with the fire?" To which the reply would come, "We are going to burn the men." 42

At dawn, the Illpongworra become decorated with various totemic symbols and, after gathering around the Kauaua, they go to the women's camp, where two bonfires are burning: Panunga-Bultara and Purula-Kumara. Men from opposing groups immerse in the smoke for about 30 seconds, then they return to the Kauaua, and the Engwura ends with the pulling out of the pole. Strehlow adds that the adepts receive

${ }^{41}$ B. Spencer, J.F. Gillen, The Arunta..., op. cit., p. 291.
${ }^{42}$ Ibidem, p. 295. 
small churinga in the form of bull-roarers called namatuna (namatwinna in Spencer and Gillen's account) and they are told to spin them as frequently as possible. ${ }^{43}$

Strehlow's informers ascribe personality and extraordinary power to the Parra. It is believed to bind the adepts, to compel them to yield to its will.

A last ceremony takes place at the foot of the tall kauaua pole. Then it is violently uprooted by the excited iliara. It is to them symbolical of the rala parra, the greatest of all sacred tjurunga, which has tormented them during the weary months of their toil on the inkura ground. They seize the pole in a body, move it up and down horizontally in front of their chests, and dance savagely around the earth-mound with the sacred pole placed on their shoulders. They 'weary it and exhaust its strength' just as the rala parra during the proceeding months wearied them and exhausted their strength and oppressed their days and nights. The iiliara rudely strip the pole of its decorations. It is flung away into a long straight column. In single file they advance sideways with shuffling steps across the sacred earth-mound. Their feet cleave a deep breach in the centre of the rala parra. The great tjuruya has been shattered; its spell has been broken; its power is no more. ${ }^{44}$

If we want to understand the significance of fire in the Engwura and its relationships with circumcision (Lartna), we need to take a closer look at its mythical foundation and consider its significance in the context of such elements as the Parra mound and the Kauaua pole. Fire is used, in the first place, within male-female relations and as a tool for purifying the initiates.

\section{The founding myth of the Engwura}

According to Spencer and Gillen's interpretation, the Engwura ceremony has a twolevel mythical foundation. First of all, it refers to the myth about the wanderings of the Achilpa clan ancestors, which began with the exodus from Wairidija (a place far south of the Arrernte territory, in the land of Luritja) under the command of the first Inkata kupitcha, i.e., the master of the ceremony. The Inkata had a pair of sacred paraphernalia called Ambilia-ekura. Availing himself of their power, he brought about the appearance of two women, Illapurinja and Lungarinia, and subsequently multiplied the churinga and spirits (kuruna) belonging to the Achilpa clan. The Kuruna entered the wombs of the women, which is how the leaders of the clan were born, among whom there were two strong men with great potency, the Tmalpunga, and two ceremony masters proficient in spinning the bull-roarers, called the Twanyirrika. This great group of the Achilpa, before entering the territory of the Arrernte, performed the first Engwura ceremony in a town called Yungara. It was performed as an end to a circumcision rite, which was conducted by the Twanyirrika on the Tmalpunga. According to the myth:

The Inkata told the two Twanyirrika men to circumcise first the two Tmalpunga men, which they did, then he said to them, Twanyirrika mbala tera (you two Twanyirrika men), twailijigga

\footnotetext{
${ }^{43}$ T.G.H. Strehlow, Arrernte Traditions, op. cit., p. 77.

${ }^{44}$ Ibidem, p. 111.
} 
kurtitta (make them all into young men), referring to all the other men who were called Illpongworra, and were then circumcised by the Twanyirrika. First of all the Twanyirrika tried to remove the foreskin by means of pieces of burning bark of the mulga tree, tidja urknulla (burning bark), but it was not successful, so they tried biting with their teeth, and found this better. The natives, describing what took place, said,

Tidja urknulla (Tidja, or burning mulga bark), yana (cannot), intunama lartna (cut lartna, or circumcise), mara (good), litchika (try), teitchilla (teeth), kakujigga (bite), Twanyirrika tera (the two Twanyirrika), Alchera (in the Alchera), worra wurtja (young men), lartna (circumcision), paira (penis), teitchilla (teeth), kakuta (bite).

This means, freely translated, that, in the Alchera, the two Twanyirrika men could not circumcise properly with burning mulga bark, so they thought it would be a good thing to try biting with their teeth. They did so and circumcised the young men by biting the penis. The Inkata kupitcha then held the first Engwura, following the instructions originally given by Numbakulla. In the middle of the ground he erected the Kauaua and on one side made the long Parra mound representing the original track of the Inkata maraknirra.

After preparing the ground, the Inkata kupitcha sent the women away under the charge of Illapurinja and Lungarinia, giving them instructions in regard to what had to do, which consisted in the preparation of fires, from some of which lighted bushes were to be thrown over the young men, and on others of which, at the close of the ceremony, the men were to kneel down in the smoke. ${ }^{45}$

In the narration cited above, processed heavily by Spencer, it is hard to find the original storyline. According to Strehlow, this myth, which is absent from The Native Tribes from 1898 but appears in The Arunta from 1927, was introduced by Spencer on the basis of information that he had received from Charlie Cooper Iriakura, a member of the central Arrernte tribe. In the western Arrernte, the wandering Inkata is (T)Malpunga (Malbayka in Strehlow's terminology ${ }^{46}$ ) himself, who does not order (others) to circumcise, but himself performs subincision on his own sons in Ljinjarilta ("The Subincised Penis"), near a large totemic centre called Ltalaltuma. It is the reason why he suffers greatly. He receives the traditional share of fat from a hunted wallaby for this service, but is not satisfied, because there is too little of it. This is because the initiated sons have stolen some of the wallaby fat and kept it for themselves. Analyses of the ceremony and mythology of fire in the Warlpiri and the Pitjantjatjara show that the myth of a greedy master of ceremony includes the motif of punishing young adepts with the use of fire. ${ }^{47}$ The song of Malbayka does not include such a motif; however, it explicitly associates the process of subincision with the erecting by Malbayka of a great Kauaua pole, painted in white and red stripes, being the equivalent of his penis and, at the same time, referring to a backbone and a spear. ${ }^{48}$ The second significant element of the complex is, in the opinion of

${ }_{45}$ B. Spencer, J.F. Gillen, The Arunta..., op. cit., pp. 366-367.

${ }^{46}$ There also exists a different Malbayka, who wandered a slightly different path, but in practice he is indistinguishable from the founder of the subincision institution. T.G.H. Strehlow, The Songs of Central Australia..., op. cit., p. 190.

${ }^{47}$ See A. Szyjewski, Australijskie ceremonie ognia. Ceremonie Wollunki u Warramunga, op. cit., pp. 235-236.

48 T.G.H. Strehlow, The Songs of Central Australia..., op. cit., pp. 404-409; C. Strehlow, Die Arrernte und Loritja Stämme..., op. cit., pp. 34-35. 
Strehlow, the transfer of power via blood. Malbanka feeds his blood to younglings (which reverses the functioning custom of drinking youths' blood by exhausted elders in the desert) and by doing so, he equips them with sacred power of a sexual context.

$[\mathrm{He}]$ was a powerful man of tremendous sexual vigour, whose advances could not be resisted by women. Like some of the other Arrernte tjilpa sires, he used to feed his sons with his life-blood; it was from him alone that they received their supernatural strength. ${ }^{49}$

The final ceremony, conducted after the subincision wounds are cured (similarly to circumcision), returns to the symbolism of fire. The young initiates must be lain down on a bonfire made by women from Eremophila (tnuruya) twigs plucked from the boys' decorations during the ceremony. Nevertheless, there is no mythical text pertaining to the Achilpa that would link fire to subincision - there is only the narration of Charlie Cooper, written down by Spencer. This report seems to be more of a description of a rite rather than a myth sensu stricto; therefore, its trustworthiness is limited. At the same time, the events described in it refer to an even older mythical layer, namely to the activity of Numbakulla, i.e., the heavenly ancestor of the Achilpa, and to the immediate heir of his sacred knowledge, called Inkata Achilpa maraknirra ("the very great cult leader of the Achilpa"). Numbakulla established the construction of the sacred Kauaua/Kauwa-auwa pole, the presence of which will be significant for the fire ceremonies in various tribes. Yet the Inkata Achilpa maraknir$r a$, the first initiated and the initial holder of the sacred power, walked through the territory of the Arrernte spreading spirit-fetuses in local totemic centres. These - which Spencer and Gillen write explicitly about in several places - were not only the spirits (kuruna) of the Achilpa clan, but they actually belonged to the majority of the known Arrernte totems. As a consequence, the Engwura becomes a rite of multiplication (similarly to the standard rites of multiplication called intichiuma, and in the version corrected by Spencer - mbanbiuma), the aim of which is to direct the sacred power of the ancestors in such a way as to increase the state of animal species inhabiting the land. According to Spencer, the Engwura is distinguished by the fact that it aims at multiplying (the number of) people. As a result, its symbolism gravitates heavily towards fertility.

In this context, the use of two main paraphernalia during the "great" Engwura becomes understandable: the Kauaua/Kauwa-auwa pole and the Ambilia-ekura (earlier transcription: Ambilyerikirra). Both of these artifacts are part of the heritage of the Achilpa clan that was left to them by the active ancestor-creator Numbakulla, who passed down the secret knowledge associated with them to the Inkata Achilpa maraknirra. By possessing them, the first ritual leader of the Achilpa was able to multiply the spirit children (kuruna), and then incorporate them into the bodies of the first people. Without going into a discussion about the status of the Ambilia-ekura described by me elsewhere, ${ }^{50}$ which Hiatt calls the uterine symbol, ${ }^{51}$ it is apparent that

49 T.G.H. Strehlow, The Songs of Central Australia..., op. cit., p. 409.

50 A. Szyjewski, Mitologia australijska jako nośnik tożsamości, Kraków 2014, pp. 144-146.

${ }^{51}$ Hiatt assumes that there is an antagonism between the male and the female sphere, reflected by two types of rites: "phallic" and "uterine" (L.R. Hiatt, Secret Pseudo-procreation Rites among the Australian 
his division cannot be made, because during the Engwura both the "uterine" and the "phallic" symbolism were used. The latter includes the Kauaua pole and the Parra mound. For this reason, it is worth taking a closer look at them.

\section{Conclusions}

Comparing the cycle of initiation rites in the Arrernte with initiation rituals in the desert tribes, we arrive at the conclusion that they are based upon an analogous symbolism of activities and ideas. The Arrernte initiations are therefore a transformation of the desert rites, in which the ritual syntagmas are distributed differently. An example supporting this thesis is the use of tall torches of the witi/widi type in the circumcision rite instead of in the "proper" fire ceremony, not lighting them, despite the presence of the symbolism of fire in the ritual songs, and the role of women in their destruction. The founding myth of the Engwura is at the same time a myth that introduces circumcision (Lartna), and both of these ritual activities are treated interchangeably in variants of the myth. The basic symbols of the Lartna, such as the warrior women with shields, the torch that analogizes the adept's life, the waninga associated with the Milky Way and, finally, the phallic and flame-colored flower of Eremophila, correspond in their meaning to the initiation symbolism found in the Warlpiri tribe, whereas the Arachitta poles, despite similarity in meaning, are used in a different manner. The same set of symbols appears in successive initiation rites in the Arrernte. The Engwura itself, as a fire ceremony, should be considered the final and crowning phase of the initiation processes. It is characterised by the presence, shared with the Western Desert, of a symbolic complex in which a special role is played by the equivalence: adepts $\equiv$ Eremophila $\equiv$ torch fire. Due to the fact that use of Eremophila, on the one hand, refers to the symbolism of the monsoon season (the greenness of the plant) and, on the other hand, to fires of the dry season (the redness of the plant and associations with the emu), it constitutes an ideal operator for the initiation process. As a consequence, the mythical-ritual complex of the fire ceremony in the Arrernte refers to the same codes as can be observed in the desert ceremonies, but organizes them into different syntagmas. The symbolic codes can be considered invariant.

Translated by Milena Kalida

Aborigines, [in:] Anthropology in Oceania: Essays Presented to Ian Hogbin, L.R. Hiatt, C. Jaywerdena (eds.), Sydney 1971, pp. 77-88). Criticism of Hiatt's concept: J. Morton, Totemism Now and then: A Natural Science of Society?, [in:] Scholar and Sceptic: Australian Aboriginal Studies in Honour of L.R. Hiatt, F. Merlan, J. Morton, A. Ramsey (eds.), Canberra 1997, pp. 151-170; and R.M. Berndt, Love Songs of Arnhem Land, Chicago 1978, p. 13. 


\section{References}

Berndt R.M., Love Songs of Arnhem Land, Chicago 1978.

Elkin A.P., The Australian Aborigines, New York 1964.

Hiatt L.R., Secret Pseudo-procreation Rites among the Australian Aborigines, [in:] Anthropology in Oceania: Essays Presented to Ian Hogbin, L.R. Hiatt, C. Jaywerdena (eds.), Sydney 1971, pp. 77-88.

Hilliard W., The People in between: The Pitjantjatjara People of Ernabella, New York 1968.

Kimber R.G., Smith M.A., An Arrernte Ceremony, [in:] Australians to 1788, D.J. Mulvaney, J.P. White (eds.), Fairfax 1987, pp. 221-237.

Mathews R.H., The Burbung of the Wiradthuri Tribes, "Journal of the Royal Anthropological Institute" 1896, vol. 25, pp. 295-318.

Mathews R.H., The Keeparra Ceremony of Initiation, "Journal of Anthropological Institute" 1897, vol. 26, pp. 320-340.

Morton J., Totemism Now and then: A Natural Science of Society?, [in:] Scholar and Sceptic: Australian Aboriginal Studies in Honour of L.R. Hiatt, F. Merlan, J. Morton, A. Ramsey (eds.), Canberra 1997, pp. 151-170.

My Dear Spencer: The Letters of F.J. Gillen to Baldwin Spencer, J. Mulvaney, H. Morphy, A. Petch (eds.), Melbourne 1997.

Report on the Work of the Horn Expedition to Central Australia, B. Spencer (ed.), London 1896, vol. IV - Anthropology.

Richmond G.S., A Review of the Use of Eremophila (Myoporaceae) by Australian Aborigines, "Adelaide Botanic Garden" 1993, no. 15 (2), pp. 101-107.

Spencer B., Gillen F.J., Across Australia, London 1912, vol. 1-2.

Spencer B., Gillen F.J., Native Tribes of Central Australia, London 1899.

Spencer B., Gillen F.J., The Arunta: A Study of a Stone Age People, London 1927.

Strehlow C., Die Aranda und Loritja Stämme in Zentral-Australien, Bd. 4, Frankfurt 1913.

Strehlow T.G.H., Aranda Traditions, Melbourne 1947.

Strehlow T.G.H., The Songs of Central Australia, Melbourne 1971.

Szyjewski A., Australijskie ceremonie ognia. Ceremonie Wollunki u Warramunga, "Studia Religiologica" 2016, vol. 49, no. 3, pp. 231-250.

Szyjewski A., Australijskie ceremonie ognia. Gadjari i Buluwandi u Warlpiri, "Studia Religiologica" 2014, vol. 47, no. 3, pp. 197-211.

Szyjewski A., Australijskie ceremonie ognia. Ogień w religii Warlpiri, "Studia Religiologica" 2014, vol. 47, no. 1, pp. 29-42.

Szyjewski A., Mitologia australijska jako nośnik tożsamości, Kraków 2014. 